\title{
ПОСЛІДОВНІСТЬ ВИКОНАННЯ РОБІТ ПРИ РЕКОНСТРУКЦІЇ 3 НАДБУДОВОЮ МАНСАРДИ
}

\author{
SEQUENCE OF IMPLEMENTATION OF WORK DURING \\ RECONSTRUCTION WITH BUILDUP OF THE MANSARD
}

Ксьоншкевич Л. М., к.т.н., доцент, Крантовська О. М., к.т.н., доцент (Одеська державна академія будівництва та архітектури, Одеса), Сунак П. О., к.т.н., доцент (Луцький національний технічний університет), Мельник О.В., к.т.н., доцент (Східносвропейський національний університет ім. Л. Українки, Луцьк), Парасюк Б. О. (Луцький національний технічний університет)

Ksonshkevych L. M., Ph.D. in Engineering, Associate Professor, Krantovska O. M., Ph.D. in Engineering, Associate Professor (Odesa State Academy of Civil Engineering and Architecture, Odesa), Sunak P. O., Ph.D. in Engineering, Associate Professor (Lutsk National Technical University), Melnyk O.V., Ph.D. in Engineering, Associate Professor (Lesya Ukrainka Eastern European National University, Lutsk), Parasiyk B. O. (Lutsk National Technical University)

Анотація. У статті описані основні принципи організації роботи при надбудові мансардного поверху в житлових будівлях, послідовність виконання робіт, визначення затрат праці та проектування календарного плану.

Summary. In the article described the basic principles of the organization of work for the mansard floor in residential buildings, the sequence of work, the definition of labor costs and the design of the calendar plan. The most economical, simple and effective technical solution for the reconstruction of buildings of any structural systems is the superstructure of mansard floors. The sequence of organization and planning of works during the reconstruction of buildings with a mansard superstructure includes: establishment of nomenclature and counting of works; choice of methods of organization of production of works; calculation of labor costs of workers and the need for rotation of machine; determination of the duration of the reconstruction works; creation of a calendar plan and schedule of work. The main work cycles for a mansard floor superstructure should include: preparatory work; dismantling works; reinforcement of existing structures (foundations, piers and attic flooring), if necessary; arrangement of a monolithic ring beam for rigidity providing; erection of mansard floor structures (walls, roof, partitions, window and door fills); arrangement of engineering systems (mansard); decoration (internal and external); commissioning of the object. The choice of methods of organization of production of works is carried out in parallel with the definition of the nomenclature and the calculation of the volume of works. It is known that the operating method combines sequential and parallel one, it eliminates the disadvantages and retains 
the advantages of each. After determining the nomenclature and choosing the method of reconstruction, we calculate the of labor consuming. The next stage is the designing of the calendar plan of reconstruction. When designing a calendar plan of reconstruction, it is necessary to ensure maximum time alignment of technological processes and their continuity, taking into account the requirements of job security.

Ключові слова: реконструкиія, організації та планування робіт, мансарда

Keywords: reconstruction, organization and planning of works, mansard

Постановка проблеми. На сьогодні реконструкція житлових будівель старої забудови міст набуває все більшого значення. При цьому, надбудова стає одним 3 найбільш затребуваних видів реконструкції особливо для тих територій міст, де відчутний дефіцит площ, придатних для нової забудови.

Надбудова дозволяє збільшити загальну площу будівлі, дає можливість придбати житло в центральній частині міста, а також підкреслює архітектурну виразність старої забудови.

Тому актуальними $є$ питання, пов'язані з особливостями виконання робіт з влаштування надбудови при реконструкції будівель

Аналіз останніх досліджень і публікацій. Питання пов'язані 3 проведенням реконструкції житлової забудови загалом, а також окремих будівель та споруд відображені в ряді наукових праць, зокрема [1-12].

Як показує вітчизняний та закордонний досвід, реконструкція існуючих житлових будинків найчастіше здійснюється в умовах обмеженого простору існуючої ущільненої міської забудови [1-6 та ін.], коли прилеглі території зайняті дорогами, площадками, зеленими насадженнями, різноманітними елементами благоустрою територій, елементами конструкцій та споруд інженерних мереж тощо, які ускладнюють розташування засобів механізації, місць прийому $\mathrm{i}$ складування матеріалів.

Мета і завдання дослідження - визначити основні етапи організації та планування робіт при реконструкції житлових будинків з надбудовою мансардного поверху.

Результати дослідження. Реконструкція житлових та громадських будівель старої забудови має достатньо широкий діапазон для прийняття рішень - модернізація, вбудова, прибудова, надбудова і влаштування квартир спеціальних типів чи підвищеного комфорту (комерційних квартир, які значно перевищують нормативні вимоги по забезпеченню житловою площею на 1 людину) [6 та ін.]. Причому, до найбільш економічних, простих та ефективних технічних рішень при реконструкції будівель будь-яких конструктивних систем належить надбудова мансардних поверхів.

Надбудова мансардних поверхів забезпечує отримання додаткової житлової площі, вартість якої не перевищує 50 \% вартості нового 
будівництва [9 та ін.]. Також $є$ можливість використання місцевих будівельних матеріалів, роботи можуть виконуватися без використання кранового обладнання, за допомогою засобів малої механізації робіт.

Послідовність організації та планування виконання робіт при реконструкції будівель з надбудовою мансарди включає:

1) Встановлення номенклатури та підрахунок обсягів робіт;

2) Вибір методів організації виробництва робіт;

3) Розрахунок затрат праці робітників і потреби в машино-змінах;

4) Визначення тривалості робіт при реконструкції;

5) Побудова календарного плану та графіку виконання робіт.

Визначаючи структуру ремонтно-будівельного виробництва, з його складу виділяються основні цикли робіт, на яких одноманітно організовується виконання технологічних процесів, проводиться розбивка об'єкта реконструкції на захватки і монтажні ділянки, проектуються спеціалізовані потоки $[10,11]$.

Основні цикли робіт при надбудові мансардного поверху повинні включати: підготовчі роботи; демонтажні роботи; підсилення, за необхідності, існуючих конструкцій (фундаментів, простінків та горищного перекриття); влаштування монолітного поясу для забезпечення жорсткості; зведення конструкцій мансардного поверху (стіни, покрівля, перегородки, віконні та дверні заповнення); влаштування інженерних систем (мансарда); оздоблення (внутрішнє та зовнішнє); введення об'єкту в експлуатацію.

Вибір методів організації виробництва робіт проводиться паралельно 3 визначенням номенклатури і підрахунком обсягів робіт.

Реконструкція будівель i споруд може бути організована послідовним, паралельним i поточним методами рис. 1. Найбільш ефективним методом організації робіт при реконструкції вважається поточний метод $[10,11]$.

При послідовному методі кожна будівля реконструюється за певний період (цикл) і тільки після закінчення попереднього.

Середня інтенсивність споживання ресурсів при цьому рівна на кожній дільниці.

Недолік такого методу виробництва робіт полягає в тому, що подовжується загальний термін реконструкції і утворюються вимушені перерви в роботі бригад, що виконують окремі процеси.

При паралельному методі всі будівлі реконструюються одночасно і термін реконструкції їх дорівнює часу реконструкції одного об'єкта. Однак при цьому потрібна максимальна кількість матеріально-технічних ресурсів.

Поточний метод поєднує послідовний і паралельний, в ньому усуваються недоліки і зберігаються переваги кожного з них. 
Реконструкція будівель потоковим методом вимагає менше часу, ніж послідовним, а найбільша кількість одночасно споживаних ресурсів буде менше, ніж при паралельному методі.

Після визначення номенклатури та вибору методу реконструкції виконується розрахунок затрат праці та потреби в машино-змінах.

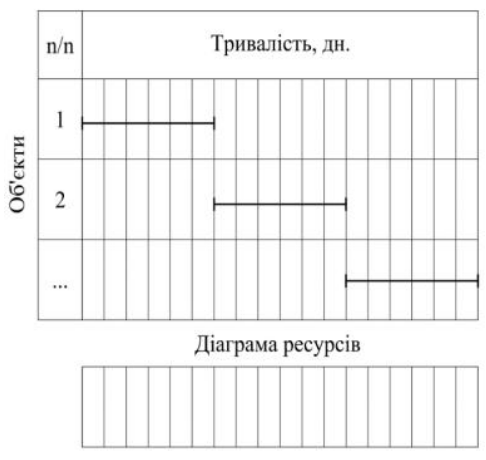

a)

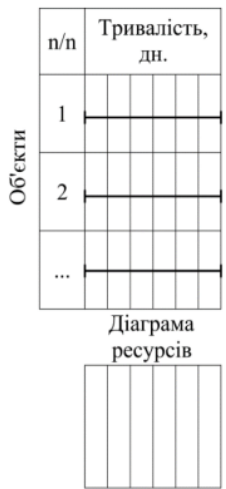

б)

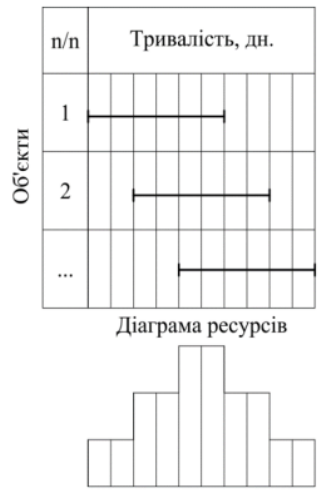

в)

Рис. 1. Графік виконання робіт та діаграма ресурсів:

а) - при послідовному методі виконання робіт; б) - при паралельному методі виконання робіт; в) - при поточному методі виконання робіт

Розрахунок затрат праці робітників і потреби в машино-змінах підраховуються за формулами (1) та (2):

$$
\begin{gathered}
\mathrm{Q}_{\mathrm{P}}=\frac{\mathrm{V}_{\mathrm{g}} \times \mathrm{H}_{\mathrm{Q} / \mathrm{p} \times 6)}}{8,2} \\
\mathrm{Q}_{\mathrm{M}}=\frac{\mathrm{V}_{\mathrm{g}} \times \mathrm{H}_{\mathrm{Q}, \mathrm{x})}}{\mathrm{T}, 5}
\end{gathered}
$$

де: $\mathrm{V}_{\mathrm{p}}$ - обсяг робіт;

$\mathrm{H}_{\text {ч(роб) }}$ - норма часу (люд-год) з РЕКН [12];

$\mathrm{H}_{\mathrm{ч}(м)}$ - норма часу (маш-год) згідно з РЕКН [12];

8,2 - тривалість зміни для робітників, год;

7,5 - тривалість розрахункового періоду роботи транспортного засобу на протязі зміни, год.

Тривалість (Т) виконання робіт при реконструкції визначається за формулою (3): 


$$
\mathrm{T}=\frac{\mathrm{V}_{\mathrm{p}} \times \mathrm{H}_{\mathrm{q}(\mathrm{x})}}{\mathrm{N} \times \mathrm{n} \times \mathrm{k}_{\mathrm{IH}}}
$$

де: Т - тривалість виконання робіт при реконструкції (дн.);

$\mathrm{N}$ - кількість прийнятих робітників у бригаді (люд);

$\mathrm{n}$ - кількість змін на добу (зм).

$\mathrm{k}_{\text {п.н. }}$ - коефіцієнт планованого перевиконання норм.

При користуванні формулою (3) величиною Т задаються, виходячи із загального строку реконструкції заданого об'єкту i необхідності технологічної та організаційної ув'язки процесів в графіку. Коефіцієнт планованого перевиконання норм приймають у межах $\mathrm{k}_{\text {п.н. }}=1 \div 1,3$.

Основні принципи, покладені в основу календарного плану суміщення робіт в часі, змінність робіт, умови технологічної ув'язки робіт, тощо. Календарний план в лінійній формі будується у вигляді таблиці 1.

Таблиця 1

Календарний план виконання робіт

\begin{tabular}{|c|c|c|c|c|c|c|c|c|c|c|c|c|c|c|c|}
\hline \multirow{3}{*}{$\begin{array}{l}\text { № } \\
\text { 3/ח }\end{array}$} & \multirow{3}{*}{ 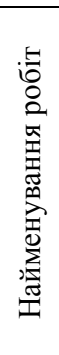 } & \multicolumn{2}{|c|}{$\begin{array}{l}\text { Обсяг } \\
\text { робіт }\end{array}$} & \multirow{3}{*}{ 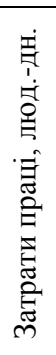 } & \multicolumn{2}{|c|}{$\begin{array}{l}\text { Потреба в } \\
\text { машинах }\end{array}$} & \multirow{3}{*}{ 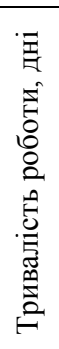 } & \multirow{3}{*}{ 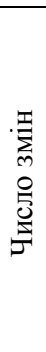 } & \multirow{3}{*}{ 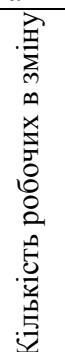 } & \multirow{3}{*}{ 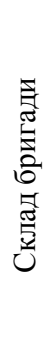 } & \multirow{2}{*}{\multicolumn{5}{|c|}{$\begin{array}{c}\text { Графік } \\
\begin{array}{c}\text { виконання } \\
\text { робіт }\end{array} \\
\text { Дні, місяці }\end{array}$}} \\
\hline & & & & & & & & & & & & & & & \\
\hline & & 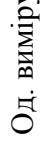 & 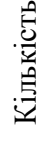 & & 总 & 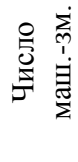 & & & & & 1 & 2 & 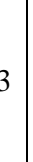 & 4 & 5 \\
\hline 1 & 2 & 3 & 4 & 5 & 6 & 7 & 8 & 9 & 10 & 01 & & & & & \\
\hline
\end{tabular}

У дві зміни організовуються роботи, які необхідно виконати в стислі терміни, а фронт їх обмежений i не дозволяє збільшити чисельність робітників у зміні, а також роботи, при виконанні яких зайняті основні будівельні машини (крани, екскаватори, скрепери, бульдозери та ін.).

При побудові календарного плану слід прагнути до максимального суміщення в часі технологічних процесів та їх безперервності 3 урахуванням вимог безпеки виконання робіт. У правій частині календарного плану (графа 12) кожен процес позначають горизонтальним відрізком прямої, довжина якої в прийнятому масштабі часу показує тривалість виконання процесу.

Для полегшення у подальшій побудові графіка потреби в робочих кадрах, над кожним з таких відрізків рекомендується надписувати число робітників i змінність робіт. Наприклад, 10х2 означає, що процес виконується десятьма робочими в кожну зміну при двозмінній роботі на 
добу. Можна також вказувати над відрізком цифрою тільки число робочих, а змінність зображати кількістю паралельних відрізків.

Висновки. При реконструкції житлових будівель 3 надбудовою мансарди немає необхідності у відведенні нових ділянок, збільшується ефективність використання існуючої забудови. Правильне проектування виробництва робіт та організаційно-технічної підготовки реконструкції забезпечує планомірне розгортання і здійснення ремонтно-будівельних робіт, закінчення реконструкції в передбачені планом терміни, виконання планових завдань зі зростання продуктивності праці i зниження собівартості робіт, а також забезпечує високу якість робіт.

\section{References}

1.Rossoxin S. O. Onovlennya mist i modernizaciya zhytlovogo fondu Ukrayiny: problemy i perspektyvy / S. O. Rossohin // Stroitelstvo, materialovedenie, mashinostroenie: sb. nauch. trudov. - Vyp. 50. - Dnepropetrovsk: PGASA, 2009. S. $455-461$.

2.Kravchunovska T. S. Do pytannya kompleksnoyi rekonstrukciyi kvartaliv / T. S. Kravchunovska // Stroitelstvo, materialovedenie, mashinostroenie: sb. nauch. trudov. Vyp. 50. - Dnepropetrovsk: PGASA, 2009. - S. 271-276.

3.Domin M. M., Byvalina M. V. Problemy` ta metody modernizaciyi rajoniv masovoyi zhytlovoyi zabudovy 60-70-x rokiv (na prykladi m. Kyiva) / M. M. Domin, M. V. Byvalina // Mistobuduvannya ta teryt. planuv.: Nauk.-texn. zbirnyk. - K: KNUBA. - 2005. - Vyp. 21. - S. 67-75.

4.Lynnyk I. E. Metody rekonstrukcii zhilyh kvartalov / I.E. Lynnyk, Y. V. Tyxonenko, S. V. Synii // Komunalne gospodarstvo mist: nauk.-texn. zb. - Xarkiv: XNAMG, 2012. - Vyp. 105. - S. 268-272.

5.Verhogljadova N. I. Kompleksnoe razvitie i planirovanie rekonstrukcii zhiloj zastrojki / N. I. Verhogljadova, D. L. Levchinskij // Stroitelstvo, materialovedenie, mashinostroenie: sb. nauch. trudov. - Vyp. 50. - Dnepropetrovsk: PGASA, 2009. S. 90-94.

6.Sunak P.O. Analiz zaxodiv rekonstrukciyi zhytlovogo fondu zakordonom / P.O. Sunak, Y.A. Melnyk, O.V. Melnyk, S. V. Synii, O.P. Sunak, I.E. Lynnyk // Mistobuduvannya ta terytorial 'ne planuvannya: nauk.-texn. zb. - K: KNUBA, 2014. Vyp. 54. - S. 397-410.

7.Parasiyk B. O. Dosvid rekonstrukciyi zhytlovyx budynkiv serednoyi poverxovosti pershyx masovyx serij / B. O. Parasiyk // Mistobuduvannya ta terytorial'ne planuvannya: nauk.-texn. zb. - K: KNUBA, 2012. - Vyp. 45(2). - S. 96-99.

8.Bulgakov S. N. Varianty proektnyh reshenij mansardnyh jetazhej pri rekonstrukcii zhilyh domov: arhitekturno-planirovochnye reshenija // Promyshlennoe i grazhdanskoe stroitelstvo. - 2000. - №1. - S. 41-44.

9.Osipov A. F. Osobennosti obemno-planirovochnyh i konstruktivnih harakteristik rekonstruiruemyh zhilyh zdanij g. Kieva / A. F. Osipov, S. F. Akimov // Stroitelstvo i tehnogennaja bezopasnost. - 2002. - Vyp. 6. - S. 260-265.

10. Dikman L. G. Organizacija stroitelnogo proizvodstva / Uchebnik dlja stroitelnyh vuzov. - M: Izdatelstvo Associacii stroitelnyh VUZov, 2006 - 608 s. 
11. Pankevych O. D. Organizaciya budivnycztva. Navchalnyj posibnyk. Vinnycya: VNTU, 2007. - 86 s.

12. DSTU B D.2.4-20:2012 Resursni elementni koshtorysni normy na remontnobudivelni roboty. Inshi remontno-budivelni roboty' (Zbirnyk 20) - Kyiv: Minregion Ukrayiny. - 2013.

\section{Література}

1.Россохін С. О. Оновлення міст і модернізація житлового фонду України: проблеми і перспективи / С. О. Россохін // Строительство, материаловедение, машиностроение: сб. науч. трудов. - Вып. 50. - Днепропетровск: ПГАСА, 2009. C. 455-461.

2.Кравчуновська Т. С. До питання комплексної реконструкції кварталів / Т. С. Кравчуновська // Строительство, материаловедение, машиностроение: сб. науч. трудов. - Вып. 50. - Днепропетровск: ПГАСА, 2009. - С. 271-276.

3.Дьомін М. М., Биваліна М. В. Проблеми та методи модернізації районів масової житлової забудови 60-70-х років (на прикладі м. Києва) [Текст] / М. М. Дьомін, М. В. Биваліна // Містобудування та терит. планув.: Наук.-техн. збірник. - К: КНУБА. — 2005. - Вип. 21. — С. 67-75.

4.Линник И. Э. Методы реконструкции жилых кварталов / И. Э. Линник, Ю. В. Тихоненко, С. В. Синий // Комунальне господарство міст: наук.-техн. зб. Харків: ХНАМГ, 2012. - Вип. 105. - С. 268-272.

5.Верхоглядова Н. И. Комплексное развитие и планирование реконструкции жилой застройки / Н. И. Верхоглядова, Д. Л. Левчинский // Строительство, материаловедение, машиностроение: сб. науч. трудов. - Вып. 50. Днепропетровск: ПГАСА, 2009. - С. 90-94.

6.Сунак П.О. Аналіз заходів реконструкції житлового фонду закордоном / П.О. Сунак, Ю.А. Мельник, О.В. Мельник, С.В. Синій, О.П. Сунак, І.Е. Линник // Містобудування та територіальне планування: наук.-техн. зб. - К: КНУБА, 2014. Вип. 54. - С. 397-410.

7.Парасюк Б. О. Досвід реконструкції житлових будинків середньої поверховості перших масових серій / Б. О. Парасюк // Містобудування та територіальне планування: наук.-техн. зб. - К: КНУБА, 2012. - Вип. 45(2). - С. 9699.

8.Булгаков С. Н. Варианты проектных решений мансардных этажей при реконструкции жилых домов: архитектурно-планировочные решения // Промышленное и гражданское строительство. - 2000. - №1. - С. 41-44.

9.Осипов А. Ф. Особенности объемно-планировочных и конструктивних характеристик реконструируемых жилых зданий г. Киева / А. Ф. Осипов, С. Ф. Акимов // Строительство и техногенная безопасность. - 2002. - Вып. 6. С. $260-265$.

10. Дикман Л. Г. Организация строительного производства / Учебник для строительных вузов. - М: Издательство Ассоциации строительных ВУЗов, 2006. $608 \mathrm{c}$.

11. Панкевич О. Д. Організація будівництва. Навчальний посібник. Вінниця: ВНТУ, 2007. - 86 с.

12. ДСТУ Б Д.2.4-20:2012 Ресурсні елементні кошторисні норми на ремонтно-будівельні роботи. Інші ремонтно-будівельні роботи (Збірник 20) - Київ: Мінрегіон України. - 2013. 